\title{
Peran Perawat Dalam Penerapan Budaya Keselamatan Pasien Di Rumah Sakit
}

\author{
Cut Tari \\ e-Mail cuttari19@gmail.com
}

\begin{abstract}
Abstrak
Latar belakang: Kurangnya kesedaran petugas medis di rumah sakit dalam menerapkan budaya keselamatan pasien di rumah sakit yang mengakibatkan banyak terjadi keselahan ketika sedang melakukan pelayanan kepada pasien ,sehingga membuat petugas kesehatan yang berada di rumah sakit harus mamu menerapkan perannya untuk menciptakan budaya keselamat pasien di rumah sakit,sehingga tidak terjadi lagi kesalahan maupun kelalaian yang dibua oleh petugas kesehatandi rumah sakit kepada pasien Tujuan:Untuk menerapkan budaya keselamatan pasien di rumah sakit Metode: Metode yang digunakan oleh penulis adalah Literature review dimana dilakukan dengan cara menganalisis kajian ,eksplorasi jurnal, maupun e-book Adapun jurnal yang digunakan pada literature review ini adalah jurnal yang diterbitkan dari kurun waktu 10 tahun terakhir yang didapatkan dengan menggunakan dua database Portal Garuda dan Google Scholar dan referensi yang digunakan sebanyak 14. Kesimpulan: Untuk menerapkan budaya keselamatan pasien di rumah sakit diperlukan kerja sama team yang baik sehingga akan diperoleh kerja sama dan memperkecil adanya keselahan ketikan melakukan tugasyang akan mempermudah kegiatan petugas kesehatan ketika menerapkan budaya keselamatan pasien.Dalam menerapkan budaya keselamatan pasien di rumah sakit dapat dilakukan atau diterapkan 7 langkah menuju keselamatan pasien .
\end{abstract}

Kata Kunci: Perawat,Keselamatan Pasien,Rumah Sakit

\begin{abstract}
Background: Lack of awareness of medical staff in hospitals in implementing a culture of patient safety in hospitals that results in a lot of discomfort while serving patients, thus making health workers in the hospital must be able to apply their role to create a culture of patient safety at home illness, so that there are no more errors or negligence made by health workers in hospitals to patients. Purpose: To implement patient safety culture in hospitals Method: The method used by the author is Literature review which is done by analyzing studies, journal exploration, and e -book The journals used in this literature review are journals published from the past 10 years obtained using the two Garuda Portal databases and the Google Scholar and references used as many as 14 . Conclusion: To apply patient safety culture $\mathrm{n}$ the hospital requires good teamwork so that cooperation will be obtained and minimize the presence of fatigue when doing tasks that will facilitate the activities of health workers when applying patient safety culture.In applying patient safety culture in hospitals can be done or applied 7 steps towards patient safety .
\end{abstract}

Keywords: Nurse, Patient Safety, Hospital 


\section{PENDAHULUAN}

\section{LATAR BELAKANG}

Patient safety atau keselamatan pasien adalah konsep pasien yang dalam pelayanan kesehatan dapat mencapai dampak yang diharapkan. Dalam hal injury, keselamatan pasien didefinisikan sebagai terbebas dari accidental injury dengan menjamin keselamatan pasien melalui penetapan sistem operasional, meminimalisasi kemungkinan kesalahan , dan meningkatkan pencegahan.

Budaya keselamatan pasien atau patient safety culture merupakan nilai, persepsi, keyakinan, sikap, kompetensi dan pola perilaku dari setiap individu yang dihasilkan oleh individual dan kelompok yang ditetapkan berdasarkan komitmen dan gaya dari manajemen organisasi kesehatan yang ada di rumah sakit untuk menjamin keselamatan pasien selama perawatan (Sammer et.al, 2009; Clancy, 2011). Penerapan budaya keselamatan pasien akan mendeteksi kesalahan yang akan terjadi atau jika kesalahan telah terjadi budaya keselamatan pasien akan meningkatkan kesadaran untuk mencegah dan melaporkan jika ada kesalahan. Budaya keselamatan pasien menurut NPSA (2004) secara garis besar dibagi mennjadi empat komponen yaitu terbuka (open), adil (justice), informatif dalam melaporkan kejadian yang terjadi (Reporting) dan belajar dari kesalahan yang ada (learning). Bersikap terbuka dan adil yang artinya berbagai informasi secara terbuka juga bebas, dan perlakukan adil bagi perawat ketika terjadi sebuah kejadian. Informasi yang akurat membantu dalam pencegahan kejadian dari keselamatan pasien (Reason, 2000). Sistem pelaporan digunakan untuk memberikan informasi kepada pihak manajerial mengenai kejadian yang terjadi dan sebagai pembelajaran sehingga kejadian yang sama tidak akan terulang lagi (Carthey \& Clarke, 2010).

Rumah sakit sebagai organisasi badan usaha di bidang kesehatan mempunyai peranan penting dalam mewujudkan derajat kesehatan masyarakat secara optimal. Maka dari itu rumah sakit dituntut agar mampu mengelola kegiatannya dengan mengutamakan pada tanggung jawab para professional di bidang kesehatan, khususnya tenaga medis dan tenaga keperawatan dalam menjalankan tugas dan kewenangannya. Tidak selamanya layanan medis yang diberikan oleh tenaga kesehatan dapat memberikan hasil yang 
sebagaimana diharapkan semua pihak. Tenaga kesehatan yang melakukan kelalaian dapat dapat disebut melakukan malpraktik. Malpraktik yang dilakukan oleh tenaga kesehatan dapat berupa malpraktik dibidang medik dan malpraktik non medik. Karena banyaknya kasus malpraktik, maka harus diterapkarr program keselamatan pasien (Patient Safety). Keselarnatan telah menjadi isu global termasuk juga isu bagi rumah sakit.

Keselamatan pasien di rumah sakit (KPRS) adalah system pelayanan dalam suatu Rumah sakit yang bertujuan untuk memberikan asuhan kepada pasien agar menjadi lebih aman, termasuk didalamnya mengukur resiko, identifikasi dan pengelolahan resiko terhadap pasien analisa insiden, kemampuan untuk belajar dan menindaklanjuti insiden serta menerapkan solusi untuk mengurangi resiko (WHO,2004). Oleh karena itu diperlukan komitmen dan ethis dalam keperawatan. Keselamatan pasien merupakan suatu system yang sangat dibutuhkan dan dengan adanya system ini diharapkan dapat meminimalisir kesalahan dalam penanganan pasien baik pada pasien UGD, rawat inap maupun pasien poliklinik (PERSI, 2008).

\section{Metode Penelitian}

Metode yang digunakan oleh penulis adalah Literature review dimana dilakukan dengan cara menganalisis kajian dan eksplorasi jurnal, text book, maupun e-book yang relevan dan membahas tentang kemampuan berpikir kritis bagi perawat.

Adapun jurnal yang digunakan pada literature review ini adalah jurnal yang diterbitkan dari kurun waktu 10 tahun terakhir didapatkan dengan menggunakan 2 database Portal Garuda dan Google Scholar dengan memasukkan kata kunci " Budaya keselamatan pasien", "peran perawat dalam keselamatan pasien",dan "keselamatan pasien di rumah sakit ".itulah kata kunci yang digunakan pada saat melakukan pencarian jurnal Artikel yang digunakan menggunakan 14 referensi.

\section{Hasil Penelitian}

Berdasarkan hasil pencarian literatur didapatkan Peran perawat dalam penerapan budaya keselamatan pasien di rumah sakit ,dimana didalam 
literature review tersebut penelitian ini mendapatkan hasil bahwa perawat memiliki peran penting dalam menerepkan budaya keselamatan pasien di rumah sakit untuk menjaga pasien dari suatu kecelekaan yang tidak di inginkan selama pasien tersebut berada di rumah sakit oleh karena itu budaya keselamatan pasien harus di jalankan di RS

Budaya Patient hasil penelitian menunjukan bahwa ,safety di tingkat unit kerja rumah sakit menunjukan $14,7 \%$ responden memberikan respons positif pada budaya patient safetydi unit rumah sakit. Jika dicermati lebih teliti, budaya patient safetyberdasarkan tiap dimensinya dapat dilihat bahwa respons positif yang paling besar $(81,7 \%)$ diberikan pada kerja sama tim di tingkat unit, sedangkan respons positif paling kecil (10,5\%) diberikan pada dimensi penyusunan staf (Elrifda,Soha.2011)

\section{Pembahasan}

Di dalam penelitian Hanya sebagian kecil responden yang "sering" atau "selalu" melaporkan kesalahan yang terjadi. Penelitian ini tidak jauh berbeda dengan penelitian yang dilakukan oleh Permanasari,4 yang meneliti tentang budaya patient safetydan alokasi biaya di Indonesia yang menunjukkan hasil 30\% jawa- ban responden mengatakan "selalu" atau "sering" mela- porkan kejadian atau kesalahan. Pelaporan tiap kesalahan yang dibuat oleh petugas merupakan suatu hal yang di- tanggapi berbeda oleh petugas. Hal ini ditunjukkan oleh kecilnya jumlah petugas yang selalu ataupun sering melaporkan kejadian atau kesalahan yang telah dilakukannya. Petugas yang melaporkan kejadian atau kesalahan adalah petugas yang telah menyadari pentingnya melaporkan kesalahan agar dapat ditindaklanjuti dan diatasi di masa yang akan datang. Sementara, petugas lainnya belum memahami pentingnya melaporkan kejadian atau karena sebab- sebab lain (misalnya takut, merasa malu atau mendapat sanksi). Kenyataan ini menunjukkan fakta bahwa diperlukan sosialisasi kepada petugas tentang pentingnya patient safety dan pelaporan kejadian kesalahan untuk upaya mengatasi masalah dan memperbaiki guna memperoleh keselamatan pasien

Ada beberapa jenis sistem pelaporan yang dapat dilakukan antara lain, yaitu mandatory reporting systemdan vo-luntary reporting system. Mandatory reporting system adalah 
sistem pelaporan bertujuan untuk membuat petugas menjaga dan bertanggung jawab terhadap kinerja yang dilakukannya. Sistem pelaporan ini difokuskan pada kesalahan yang berhubungan dengan cedera serius atau kematian.

Dengan memberi reward kepada tim dapat membantu menyelesaikan tugasnya dengan baik serta memberikan sanksi pada tim yang tidak dapat menyelesaikan tugasnya dengan baik. Pola reward serta punishmentyang konsisten dan berbasis kinerja dapat memberikan harapan pada petugas dan meningkatkan motivasi kerjanya.

Kesalah yang dilakukan oleh petugas yang berada di rumah sakit meliputi kesalahan dalam kedisipilinan, komunikasi, hingga kesalahan teknis. Penyebab kesalahantersebut dapat terjadi paling banyak dikemukakan responden adalah salah informasi. Kesalahan informasi salah satunya oleh komunikasi yang buruk sehingga petugas tidak memahami dengan jelas apa yang dibicarakan atau pesan yang disampaikan. Hasil penelitian ini selaras dengan penjelasan dalam Journal of the Royal Society of Medicinebahwa penyebab kesalahan pelayanan adalah kegagalan sistem, dalam hal ini berupa komunikasi yang buruk. Selain itu, penyebab kesalahan pelayanan oleh petugas adalah kurangnyaa pengetahuan petugas yang luas sehingga petugas tidak dapat melakukan tugasnya dengan baik. Kesalahan pelayanan kesehatan dapat disebabkan oleh faktor manusia, seperti contohnya variasi pendidikan, training, dan pengalaman petugas yang memberikan pelayanan kesehatan . Penyebab lainnya yang banyak dikemukakan oleh respoden adalah kelalaian petugas rumah sakit karena kurang hati-hati, tertidur, ataupun karena aktivitas lain. Kelalaian petugas dimungkinkan oleh berbagai hal, antara lain karena volume kerja yang begitu tinggi atau karena tekanan waktu sehingga mengurangi konsentrasi petugas atau dapat mengakibatkan kelelahan.Salah satu sebab kesalahan pelayanan yang dikemukakan oleh 2 dari 34 responden yang mengaku melakukan kesalahan adalah faktor sarana atau peralatan. Kurangnya peralatan dapat membatasi tindakan yang harus dilakukan oleh petugas, sementara petugas dituntut melakukan tindakan tertentu sehingga hal itu dapat menyulitkan petugas kesehatan yang berada di rumah sakit. Sebagaimana 
dikemukakan oleh World Health Organization (WHO) bahwa jika ada kegagalan sistem (salah satunya infrastruktur) dapat menyebabkan tindakan yang tidak

Berbagai penyebab kesalahan pelayanan yang dilakukan petugas tersebut, dapat diringkas menjadi 2 hal, yaitu faktor manusia dan kegagalan sistem. Kedua area ini bisa diperbaiki dengan beberapa langkah. Langkah pertama yaitu melakukan analisis kebijakan yang ada, apakah perlu suatu sistem itu dapat diubah atau ditingkatkan. Langkah kedua yaitu intervensi pada tingkat pimpinan, intervensi pada tingkat petugas, dan pada tingkat pasien atau klien serta keluarganya. Dalam menerapkan patient safety di rumah sakit, Kementerian Kesehatan Republik Indonesia telah menerbitkan Panduan Nasional Keselamatan Pasien (Patient Safety) di Rumah Sakit tahun 2008 yang terdiri dari 7 standar, yaitu: 1. hak pasien, 2. mendidik pasien dan keluarga, 3. keselamatan pasien dan kesinambungan pelayanan, 4. penggunaan metode peningkatan kinerja untuk melakukan evaluasi dan program, 5. peningkatan keselamatan pasien, 6. mendidik staf tentang keselamatan kerja, dan 7.komunikasi merupakan kunci bagi staf untuk mencapai keselamatan pasien yang baik di rumah sakit. Untuk mencapai ketujuh standar tersebut, Panduan Nasional menganjurkan 7 Langkah Menuju Keselamatan Pasien Rumah Sakit, diman ke tujuh itu adalah: 1. bangun kesadaran akan keselamatan pasien, 2. pimpin staf, 3. integrasikan aktivitas pengelolaan risiko, 4 . kembangkan sistem pelaporan, 5. libatkan dan berkomunikasi dengan pasien, 6. belajar dari berbagai pengalaman tentang keselamatan pasien, dan 7. cegah cedera melalui implementasi sistem keselamatan pasien. Ketujuh langkah tersebut dibuat dalam 2 tingkat dalam penerapan yaitu untuk tingkat rumah sakit dan tingkat unit/tim melalui 3 fase yaitu persiapan,pelaksanaan ,dan evaluasi.

\section{Kesimpulan Dan Saran}

Untuk menerapkan budaya keselamatan pasien di rumah sakit diperlukan kerja sama team yang baik sehingga akan diperoleh kerja sama dan memperkecil adanya keselahan ketikan melakukan tugasyang akan mempermudah kegiatan petugas kesehatan ketika menerapkan budaya keselamatan pasien.Dalam menerapkan 
budaya keselamatan pasien di rumah sakit dapat dilakukan atau diterapkan 7 langkah menuju keselamatan pasien .

Diperlukan sosialisasi kepada petugas tentang pentingnya patient safety dan pelaporan kejadian kesalahan untuk upaya mengatasi masalah dan

\section{REFERENSI}

Elrifda, S. (2011). Budaya patient safety dan karakteristik kesalahan pelayanan: implikasi kebijakan di salah satu rumah sakit di Kota Jambi. Kesmas: National Public Health Journal, 6(2), 67-76.

Harus, B. D., \& Sutriningsih, A. (2015). Pengetahuan Perawat tentang Keselamatan Pasien dengan Pelaksanaan Prosedur Keselamatan Pasien Rumah Sakit (KPRS) di Rumah Sakit Panti Waluya Sawahan Malang. Care: Jurnal Ilmiah Ilmu Kesehatan, 3(1), 25-32.

Irawan, A. G., Yulia, S., \& Mulyadi, M. (2017). Hubungan supervisi memperbaiki keselamatan pasien,lalu kerja sama tim dalam suatu ruangan harus di tingkatkan serta pemberian reward kepada tim juga dapat meningkatkan yang membuat motivasi dalam menerapkan budaya keselamatan pasien menjadi lebih tinggi.

dengan penerapan budaya keselamatan pasien di Ruang Rawat Inap Rumah Sakit XX. Masker Medika, 5(1), 241254.

Mandriani, E., Hardisman, H., \& Yetti, H. (2019). Analisis Dimensi Budaya Keselamatan Pasien Oleh Petugas Kesehatan di RSUD $d r$ Rasidin Padang Tahun 2018. Jurnal Kesehatan Andalas, 8(1), 131-137.

Mudayana, A. A. (2015). Peran Aspek Etika Tenaga Medis dalam Penerapan Budaya Keselamatan Pasien di Rumah Sakit. Majalah Kedokteran Andalas, 37, 69-74. 
Nivalinda, D., Hartini, M. I., \& Santoso,

A. (2013). Pengaruh motivasi perawat dan gaya kepemimpinan kepala ruang terhadap penerapan budaya keselamatan pasien oleh perawat pelaksana pada rumah sakit pemerintah di Semarang. Jurnal Manajemen Keperawatan, 1(2).

Pujilestari, A., Maidin, A., \& Anggraeni, R. (2016). Budaya Keselamatan Pasien di Instalasi Rawat Inap RSUP DR. Wahidin Sudirohusodo Kota Makassar. Media Kesehatan Masyarakat Indonesia, 10(1), 57-64.

Setiowati, D. (2010). Hubungan Kepemimpinan Efektif Head Nurse dengan Penerapan Budaya Keselamatan Pasien oleh Perawat Pelaksana di RSUPN Dr. Cipto Mangkusumo Jakarta. Cipto Mangunkusumo Jakarta

[Tesis]. Depok: Universitas Indonesia, 7.

Simamora,R.H..(2018) Buku Ajar Keselamatan Pasien Melalui Timbang Terima Pasien
Berbasis Komunikasi Efektif : SBAR.

Sukarip, S., Haryati, T. S., Lestari, A., Purnamaria, M., Dja'afara, C., Nonaria, L., ... \& Gautami, E. (2019). Peningkatan Pendidikan Pasien dan Keluarga dengan Penguatan Peran Interpersonal Champion Promosi Kesehatan dengan Pendekatan Peplau. The Journal of Hospital Accreditation, 1(1).

Surahmat, R., Neherta, M., \& Nurariati, N. (2019). Hubungan Karakteristik Perawat terhadap Pelaksanaan Sasaran Keselamatan Pasien Pasca Akreditasi Rumah Sakit " $X$ ” di Kota Palembang Tahun 2018. Jurnal Ilmiah Universitas Batanghari Jambi, 19(1), 1-10.

Ritonga, E. P., \& Gulo, E. K. (2019). Hubungan Fungsi Manajemen Kepala Ruangan Dengan Kepatuhan Perawat Pelaksana Dalam Penerapan Patient Safety Di Rumah Sakit Umum Imelda Pekerja Indonesia Medan. Jurnal Ilmiah 
Keperawatan Imelda, 5(2), Yulia, S., Hamid, A. Y. S., \& 624-628.

Mustikasari, M. (2012).

Widiasari, W., Handiyani, H., \& Peningkatan pemahaman Novieastari, E. (2019). Kepuasan Pasien Terhadap Penerapan Keselamatan Pasien Di Rumah Sakit. Jurnal Keperawatan Indonesia, 22(1), perawat pelaksana dalam penerapan keselamatan pasien melalui pelatihan keselamatan pasien. Jurnal Keperawatan Indonesia, 15(3), 185-192. 43-52. 